\title{
Conceptual Model for Measuring Transparency of Inter-Organizational Information Systems in Supply Chain: Case Study of Cosmetic Industry
}

\author{
Maryam Toofani ${ }^{1}$, Alireza Hassanzadeh ${ }^{2 *}$ \\ Department of information Technology Management, \\ Faculty of Management, Tarbiat Modares University, \\ Tehran, Iran.
}

\author{
Ali Rajabzadeh Ghatari ${ }^{3}$ \\ Industrial Management Department, Faculty of \\ Management, Tarbiat Modares University, \\ Tehran, Iran.
}

\begin{abstract}
The role of information systems has changed effectively in organizational performance, and today, information systems are creating value for organizations. This study aims to provide a conceptual model for measuring the transparency of inter-organizational information systems in the supply chain. The statistical population of this research includes all managers and staff of cosmetic cosmetics companies in Tehran while companies are engaged in different sectors and their number is 500. About 218 people were questioned through the calculation with the Cochran formula. A conceptual model for measuring the transparency of inter-organizational information systems in the supply chain was developed based on a review of the theoretical concepts. Researcher made questionnaire have been used to measure variables of the research model. The validity of the research tool was confirmed by experts and the reliability of the tool was reported 0.85 by Cronbach's alpha. According to Tstatistics, transparency of resources, inter-organizational trust, and environmental assurance are positive and significant in measuring transparency of inter-organizational information systems at a level of 0.01 and they are above average.
\end{abstract}

Keywords-Transparency of information systems; supply chain; cosmetic industry, measuring transparency; interorganizational

\section{INTRODUCTION}

Research on transparency of inter-organizational information systems in supply chain is not only scientifically important, but also vital to Iran's industry in current circumstances. The problems with information systems of supply chain logistics of the Iranian cosmetic industry are not only due to its technical nature, but also due to the lack of transparency and participatory communication between various inter-institutional parts of the information systems of this chain; these problems become more complicated by continuous changes in technology. Currently, significant role of information and communication technology (ICT) in coordinating intra-organizational activities is to a degree that it is regarded as the core of supply chain management. Transparency of information systems provides new business opportunities in line with economic and executive power of organizations.

The global competitive market and the changing needs of customers have led organizations to broadly focus on improving supply chain performance [1]. A complex performance management system involves many management processes such as identifying measurement scales, setting targets, planning, communicating, monitoring, reporting, and feedback. These processes are embedded in most of the information system outputs. These system outputs perform measurement and monitoring operations on key performance indicators (KPIs) that are decisive for optimizing the supply chain performance. Performance measurement is vital for companies to improve the efficiency of the supply chain and performance [2]. The supply chain involves a network of contributors and different operating channels from within and outside the organization that affect the utility of supply chain gains [3]. Nowadays, the efficient supply chain is a potential way to maintain competitive advantage and improve organizational performance. Thus, there is no competition among organizations, but it is among supply chains and it is shown that more efficient supply chain performance improves the efficiency of the organization [4]. Moreover, the role of information systems has changed effectively in organizational performance, and today, information systems are creating value for organizations [5]. Supply chain management studies emphasize the importance of integrating in-house information and its role in the supply chain [6]. Information technology in the supply chain (SC) has changed the nature of business competition and cooperation from one company to another and from the supply chain to another supply chain [7]. In the competition of supply chains, transparency through enterprise information systems (IOS) is a key determinant of supply chain competition [8]. Definition of visibility and transparency of the supply chain means that availability of suppliers or the sharing of information in a supply chain is met as they are considered as key concepts and applications of their operations and, in their view, they take advantage of mutual benefits. Recognizing the central role of the information system in supply chain transparency and visibility, researchers in both Supply Chain Management (SCM) and Information Systems (IS) have investigated the sharing of information between enterprises through organizational information systems [9]. According to Barratt and Oke [10], the result of the transparency of sharing information can clearly lead to improved operational performance of a supply chain. Wei and Wang [11] also state that supply chain transparency has a direct impact on the strategic performance of the supply chain. 
Today, the use of cosmetics is an integral part of life and as Iran is the second largest cosmetics consumer in the Middle East and the seventh importer of cosmetics in the world [12]. The cosmetics and beauty industry is one of the world's largest and most prosperous industries. According to a study about the size of the cosmetics market in Iran by the central bank and other official Iranian sources, there is no information on the share of cosmetics in the Iranian households' basket. Declaring that $30 \%$ cosmetics in the Middle East are consumed in Iran, TMBA Statistical Institute announced that Iran is the seventh country in the consumption of cosmetics industry. According to Baharat Research Center in London, the size of the cosmetics market in Iran in 2007 was estimated at \$ 2 billion. According to a research conducted by the International Research Institute, now this figure in Iran is now estimated at \$ 5 billion (Journal of Top Economics, 2015). In explaining the supply chain issue, it should be acknowledged that information in a supply chain is a key tool in the present day in decision making for the survival and development of enterprises. The link between all operations and processes in the supply chain is performed through information; expansion of these communications will enable firms in a supply chain to make the right decisions in order to develop themselves and maximize the profitability of the supply chain [13]. With these lines and models proposed for of information systems in the supply chain, the dimensions, and variables of transparent communications space, the existence of specific accesses, and the use of IT specific standards have been less explored. Moreover, this research focuses on transparency of interorganizational information systems that add the innovation of this paper. Accordingly, this research has been conducted to investigate the dimensions of transparency of interorganizational information systems in the supply chain in the cosmetic industry. Hence, the research seeks to identify dimensions of transparency of inter-organizational information systems in the supply chain of the cosmetic industry. In order to identify the dimensions of transparency of interorganizational information systems, the variables of transparency of resources, inter-organizational trust and environmental assurance are considered as dimensions of transparency of inter-organizational information systems in the supply chain.

\section{THEORETICAL FOUNDATIONS}

\section{A. Transparency of Information Systems:}

Information systems play the role of integration and coordination between different supply chain segments and the efficiency of this system has a direct impact on the performance of supply chain performance. Definition of visibility and transparency of the supply chain means that availability of suppliers or the sharing of information in a supply chain is met as they are considered as key concepts and applications of their operations and, in their view, they take advantage of mutual benefits. Recognizing the central role of the information system in supply chain transparency and visibility, researchers in both Supply Chain Management (SCM) and Information Systems (IS) have investigated the sharing of information between enterprises through organizational information [9].

\section{B. Organizational Trust:}

Organizational trust sources, for example, familiarity through reciprocal interaction, are calculated based on the interests and norms that lead to predictability and reliability. Organizational trust involves a specific relationship, because it represents the level of trust in the partner organization that has been created by the members of an organization [14].

\section{Lack of Environmental Assurance:}

Lack of environmental assurance refers to the lack of information on environmental factors that influence decisionmaking [15]. Researchers emphasize the importance of sharing information in support of the supply chain [16]. Sharing better information will lead to better performance [17]. This initial uncertainty of the environment faced by supply chain participants is affected by demand fluctuations and industry speed [17].

\section{Environmental Assurance:}

It is assurance about the privacy and compliance with information security in the system [16].

\section{E. Supply Chain:}

Supply chain involves a network of contributors and different operating channels from within and outside the organization that affects the utility of supply chain gains [3]. In addition to goods and services, this chain also includes a dynamic and continuous flow of information between different steps [1].

\section{LITERATURE REVIEW}

In a study entitled "Investigating the relationship between supply chain complexity and financial performance by reviewing the moderating role of the complexity of manufacturing companies in Khuzestan Province," Bagheri's findings [18] indicate that reducing and managing complexity in the supply chain leads to better performance, lower costs, and more integrated supply chain. Therefore, controlling and managing the level of complexity can be considered as a strategic issue for companies. This highlights the need to address complexity as a management issue. Hofmann et al. [19] investigated the relationship between supply chain management and operating costs. The research aimed to summarize and analyze what is known regarding activity-based costing (ABC) applications in the context of supply chain management (SCM). The review illustrated four main areas for further research: determination of the role of management accounting in SCM (including supply chain finance), integration of time-driven $\mathrm{ABC}$ with radio frequency identification (RFID) technology and automatic data collection, analysis of inter-organizational management tools in supply chains in multiple negotiation rounds, and standardization of cost accounting data in supply chains. Lee et al. [20] conducted a research on transparency of organizational information systems and supply chain performance with the aim of examining the impact of transparency of organizational information systems and supply chain performance. The results show that transparency of organizational information systems has a positive impact on supply chain performance; it was measured this study as operational performance. According to 
the transparency of organizational information systems, factors such as property attributes, organizational trust, complementary resources, and shared governance structures are important while lack of environmental assurance and interdependence do not have a significant effect on supply chain performance. Ignoring transparency of resources, environmental assurance, and IT standards can be considered as the weakness of this research. Ayağ et al. [21] have identified the support requirements and supply chain management strategies in the dairy industry. They used the Fuzzy Quality Function Deployment method to understand the requirements of customers and their entry into the design of the chain. Information on the quality of goods and services is one of the most important sources of uncertainty in supply chain modeling, because they are the perception and conceptual perceptions of the outside world. This paper addresses these uncertainties about the quality and customer satisfaction.

\section{RESEARCH METHODOLOGY}

This research can be considered as an applied research since the present study attempts to present a conceptual model for measuring the transparency of inter-organizational information systems in the supply chain in cosmetic industry. The statistical population of the present study consists of two varieties of management experts in the supply chain with research background and industry experts who are experts in the field of cosmetic industry, which are active in their respective companies. For sampling in this study, a random sampling method is used and the number of samples is calculated using the Cochran formula. With the reference to authoritative databases and cosmetic industry companies, the number of members of the statistical community consists of academic experts and industry professionals was estimated 500 industry professionals; in this regard, 218 academic experts and industry professionals are selected as the statistical sample of the research. Descriptive and inferential statistics have been used to analyze the data in this study. In the descriptive part, mean, and standard deviation will be used; in inferential part, Kolmogorov-Smirnov tests, Lawshe content validity and onesample t-test were used. Data were analyzed using SPSS-23 software.

In this research, an alpha value of 0.7 and higher is considered suitable for instrument reliability That reports in the Table 1. Therefore, measurements reliability is performed using Cronbach's alpha and SPSS 23 software.

TABLE I. RELIABILITY OF THE RESEARCH TOOL

\begin{tabular}{|c|c|c|c|}
\hline & Subscale & Questions & $\begin{array}{l}\text { Cochran } \\
\text { alpha }\end{array}$ \\
\hline \multirow{3}{*}{$\begin{array}{l}\text { Transparency of } \\
\text { information } \\
\text { systems }\end{array}$} & $\begin{array}{l}\text { transparency of } \\
\text { resources }\end{array}$ & $16-18$ & 0.89 \\
\hline & $\begin{array}{l}\text { inter-organizational } \\
\text { trust }\end{array}$ & $11-15$ & 0.80 \\
\hline & $\begin{array}{l}\text { environmental } \\
\text { assurance }\end{array}$ & $6-10$ & 0.82 \\
\hline
\end{tabular}

\section{A. Main hypothesis:}

A conceptual model for measuring transparency of interorganizational information systems in the supply chain includes three dimensions of transparency of resources, interorganizational trust, and environmental assurance.

\section{B. Secondary Hypotheses:}

1) Transparency of resources is a dimension of measuring transparency of inter-organizational information systems in the supply chain.

2) Inter-organizational trust is a dimension of measuring transparency of inter-organizational information systems in the supply chain.

3) Environmental assurance in environmental systems is a dimension of measuring transparency of inter-organizational information systems in the supply chain.

\section{RESEARCH FINDINGS}

\section{A. Descriptive Statistics}

Table 2 reports indexes of descriptive statistics for the sample included the mean and standard deviation, and variance for the variables studied in this research.

TABLE II. DESCRIPTIVE INDEXES OF RESEARCH VARIABLES

\begin{tabular}{|l|l|l|l|l|}
\hline Variables & $\begin{array}{l}\text { Number } \\
\text { of } \\
\text { samples }\end{array}$ & Mean & $\begin{array}{l}\text { Standard } \\
\text { deviation }\end{array}$ & Variance \\
\hline $\begin{array}{l}\text { transparency } \\
\text { of resources }\end{array}$ & 218 & 3.34 & 2.96 & 8.65 \\
\hline $\begin{array}{l}\text { inter- } \\
\text { organizational } \\
\text { trust }\end{array}$ & 218 & 3.24 & 1.85 & 6.54 \\
\hline $\begin{array}{l}\text { environmental } \\
\text { assurance }\end{array}$ & 218 & 3.74 & 1.36 & 9.69 \\
\hline
\end{tabular}

\section{B. Evaluation of Research Data Normality}

Kolmogorov-Smirnov test was used to test the data. Given that parametric methods are used in societies with normal functions and nonparametric methods are used in nonnormalized societies, normal or abnormal distribution of research data should be examined at first. KolmogorovSmirnov (KS) test is employed in this regard. If the research data is normal, Pearson correlation coefficient will be used and otherwise $\mathrm{t}$ a nonparametric method, will be used to test the research hypotheses.

TABLE III. KOLMOGOROV SMIRNOV TEST TO EXAMINE RESEARCH VARIABLES NORMALITY $(\mathrm{N}=218)$

\begin{tabular}{|l|l|l|l|}
\hline Variables & Status & $\mathbf{Z}$ & Sig. (2-tailed) \\
\hline $\begin{array}{l}\text { transparency of } \\
\text { resources }\end{array}$ & Independent & 0.956 & 0.502 \\
\hline $\begin{array}{l}\text { inter-organizational } \\
\text { trust }\end{array}$ & Independent & 0.875 & 0.458 \\
\hline $\begin{array}{l}\text { environmental } \\
\text { assurance }\end{array}$ & Independent & 0.698 & 0.387 \\
\hline
\end{tabular}

According to Table 3, Kolmogorov-Smirnov test shows that significance level for all variables not significant and data distribution is normal. Then, T-test and ANOVA variance are used to examine the research hypotheses. Questions from 16 to 18 of the questionnaire were used to measure the transparency variable. Frequency, mean, and standard deviation of responses are given in Table 4: 
TABLE IV. FREQUENCY OF RESPONDENTS' ANSWER OF TRANSPARENCY OF RESOURCES

\begin{tabular}{|l|l|l|l|}
\hline Items & Frequency & Mean & $\begin{array}{l}\text { Standard } \\
\text { deviation }\end{array}$ \\
\hline $\begin{array}{l}\text { Item 16: Use of information } \\
\text { systems of mutual benefit }\end{array}$ & 218 & 3.34 & 1.36 \\
\hline $\begin{array}{l}\text { Item 17: Relationships } \\
\text { Between Manufacturers of } \\
\text { Cosmetic Industry }\end{array}$ & 218 & 3.24 & 1.14 \\
\hline Item 18: Access to information & 218 & 3.74 & 1.09 \\
\hline
\end{tabular}

As represented in Table 4, three items have been employed to measure transparency of resources; they are responded by 218 research subjects. As shown, means response to Item 16 (3.34), item 17 (3.45) and item 18 (3.58) are obtained and all means are higher than average.

Questions from 11 to 15 of the questionnaire were used to measure the variable of inter-organizational trust. Frequency, mean, and standard deviation of responses are given in Table 5.

TABLE V. FREQUENCY OF RESPONDENTS' ANSWER TO INTERORGANIZATIONAL TRUST

\begin{tabular}{|l|l|l|l|}
\hline Items & $\begin{array}{l}\text { Standard } \\
\text { deviation }\end{array}$ & Mean & Frequency \\
\hline $\begin{array}{l}\text { Item 11: mutual respect between } \\
\text { managers and employees }\end{array}$ & 218 & 3.65 & 1.05 \\
\hline $\begin{array}{l}\text { Item 12: An Intimate and Intimate } \\
\text { Relationship Between Employees } \\
\text { and Managers }\end{array}$ & 218 & 3.40 & 1.28 \\
\hline $\begin{array}{l}\text { Item 13: Observing human aspects } \\
\text { in a competitive environment }\end{array}$ & 218 & 3.28 & 1.15 \\
\hline $\begin{array}{l}\text { tem 14: helping each other in cases } \\
\text { of crisis }\end{array}$ & 218 & 3.91 & 1.12 \\
\hline $\begin{array}{l}\text { Item 15: The relationship between } \\
\text { products based on honesty and truth }\end{array}$ & 218 & 3.63 & 1.10 \\
\hline
\end{tabular}

As represented in Table 5, five items have been employed to measure inter-organizational trust; they are responded by 218 research subjects. As shown, means response to Item 11 (3.65), item 12 (3.40), item 13 (3.28), item 14 (3.91), and item 15 (3.63) are obtained and all means are higher than average.

Questions from 6 to 10 of the questionnaire were used to measure the variable of environmental assurance. Frequency, mean, and standard deviation of responses are given in Table 6.

TABLE VI. TABLE 4. FREQUENCY OF RESPONDENTS' ANSWER TO ENVIRONMENTAL ASSURANCE

\begin{tabular}{|l|l|l|l|}
\hline Items & $\begin{array}{l}\text { Standard } \\
\text { deviation }\end{array}$ & Mean & Frequency \\
\hline $\begin{array}{l}\text { Item 6: Human Resources Privacy } \\
\text { Policy }\end{array}$ & 218 & 2.97 & 1.07 \\
\hline $\begin{array}{l}\text { Item 7: Information Exchange } \\
\text { Security }\end{array}$ & 218 & 3.71 & 1.05 \\
\hline Item 8: industry market stability & 218 & 3.37 & 1.10 \\
\hline $\begin{array}{l}\text { Item 9: Share information between } \\
\text { production }\end{array}$ & 218 & 3.57 & 1.21 \\
\hline $\begin{array}{l}\text { Item 10: Rules and regulations in } \\
\text { terms of effectiveness }\end{array}$ & 218 & 3.41 & 2.2 \\
\hline
\end{tabular}

As represented in Table 6, five items have been employed to measure of environmental assurance; they are responded by 218 research subjects. As shown, means response to Item 6 (2.97), item 7 (3.71), item 8 (3.37), item 9 (3.57), and item 10 (3.41) are obtained and all means except item 5 are higher than average.

\section{First Hypothesis Testing and Analysis:}

Transparency of resources is a dimension of measuring transparency of inter-organizational information systems in the supply chain.

The first hypothesis suggests that the transparency is considered as an independent variable. Lawshe test is used to examine content validity of research items. Table 7 reports the value of CVE index resulted from experts' opinion; all indexes are higher than 0.50 indicating the high validity of items representing transparency of resources.

TABLE VII. CONTENT VALIDITY OF STATEMENTS IN THE QUESTIONNAIRE OF TRANSPARENCY OF RESOURCES IN SUPPLY CHAIN

\begin{tabular}{|l|l|l|l|l|}
\hline Questions & Variable & Accept & Reject & CVR \\
\hline 16 & \multirow{3}{*}{$\begin{array}{l}\text { transparency of } \\
\text { resources }\end{array}$} & 11 & 1 & 0.83 \\
\cline { 3 - 5 } & & 12 & - & 1 \\
\cline { 3 - 5 } 18 & 12 & - & 1 \\
\hline
\end{tabular}

Moreover, One-sample T-test has been used to test first hypothesis. The results are shown in Table 8.

TABLE VIII. DESCRIPTIVE INDICATORS OF TRANSPARENCY OF RESOURCES IN THE SUPPLY CHAIN

\begin{tabular}{|l|l|l|}
\hline Mean & Standard deviation & Mean standard error \\
\hline 3.34 & 3.11 & 11.70 \\
\hline
\end{tabular}

TABLE IX. ONE-SAMPLE T-TEST FOR EVALUATING TRANSPARENCY OF RESOURCES IN THE SUPPLY CHAIN

\begin{tabular}{|l|l|l|l|}
\hline T-statistics & $\begin{array}{l}\text { Freedom } \\
\text { degree }\end{array}$ & Significance level & $\begin{array}{l}\text { Mean } \\
\text { difference }\end{array}$ \\
\hline 5.57 & 217 & 0.01 & 0.30 \\
\hline
\end{tabular}

According to Table 9, T-statistics of transparency of resources in supply chain is positive and significant at the level of 0.01 ; it is higher than average. In other words, transparency of resources is a dimension of measuring transparency of interorganizational information systems in the supply chain.

\section{Second Hypothesis Testing and analysis:}

Inter-organizational trust is a dimension of measuring transparency of inter-organizational information systems in the supply chain.

The second hypothesis suggests that inter-organizational trust is considered as an independent variable. Lawshe test is used to examine content validity of research items. The following table reports the value of CVE index resulted from experts' opinion; all indexes are higher than 0.50 indicating the high validity of items representing inter-organizational trust.

TABLE $X$. TABLE 9. CONTENT VALIDITY OF STATEMENTS IN THE QUESTIONNAIRE OF INTER-ORGANIZATIONAL TRUST IN SUPPLY CHAIN

\begin{tabular}{|l|l|l|l|l|}
\hline Questions & Variable & Accept & Reject & CVR \\
\hline 11 & \multirow{4}{*}{$\begin{array}{l}\text { Inter-organizational } \\
\text { trust }\end{array}$} & 12 & - & 1 \\
\cline { 4 - 5 } & & 11 & 1 & 0.83 \\
\cline { 4 - 5 } & & 12 & - & 1 \\
\cline { 4 - 5 } & & 11 & 1 & 0.83 \\
\hline 13 & & 12 & - & 1 \\
\hline 15 & &
\end{tabular}

TABLE XI. DESCRIPTIVE INDICATORS OF INTER-ORGANIZATIONAL TRUST IN THE SUPPLY CHAIN

\begin{tabular}{|l|l|l|}
\hline Mean & Standard deviation & Mean standard error \\
\hline 3.24 & 3.54 & 10.21 \\
\hline
\end{tabular}


Moreover, one-sample T-test has been used to test second hypothesis. The results are shown in Table 11.

TABLE XII. ONE-SAMPLE T-TEST FOR EVALUATING INTERORGANIZATIONAL TRUST IN THE SUPPLY CHAIN

\begin{tabular}{|l|l|l|l|}
\hline T-statistics & $\begin{array}{l}\text { Freedom } \\
\text { degree }\end{array}$ & Significance level & Mean difference \\
\hline 9.25 & 217 & 0.01 & 0.45 \\
\hline
\end{tabular}

According to Table 12, T-statistics of inter-organizational trust (9.25) in supply chain is positive and significant at the level of 0.01 ; it is higher than average. In other words, interorganizational trust is a dimension of measuring transparency of inter-organizational information systems in the supply chain.

\section{E. Third Hypothesis Testing and analysis:}

Environmental assurance in environmental systems is a dimension of measuring transparency of inter-organizational information systems in the supply chain.

The second hypothesis suggests that environmental assurance is considered as an independent variable. Lawshe test is used to examine content validity of research items. Table 13 reports the value of CVE index resulted from experts' opinion; all indexes are higher than 0.50 indicating the high validity of items representing environmental assurance.

TABLE XIII. CONTENT VALIDITY OF STATEMENTS IN THE QUESTIONNAIRE OF ENVIRONMENTAL ASSURANCE IN SUPPLY CHAIN

\begin{tabular}{|c|c|c|c|c|}
\hline Questions & Variable & Accept & Reject & CVR \\
\hline 6 & \multirow{5}{*}{$\begin{array}{l}\text { Environmental } \\
\text { assurance }\end{array}$} & 12 & - & 1 \\
\hline 7 & & 11 & 1 & 0.83 \\
\hline 8 & & 10 & 2 & 0.67 \\
\hline 9 & & 12 & - & 1 \\
\hline 10 & & 12 & - & 1 \\
\hline
\end{tabular}

Moreover, one-sample T-test has been used to test second hypothesis. The results are shown in Table 14.

TABLE XIV. DESCRIPTIVE INDICATORS OF ENVIRONMENTAL ASSURANCE IN THE SUPPLY CHAIN

\begin{tabular}{|l|l|l|}
\hline Mean & Standard deviation & Mean standard error \\
\hline 8.34 & 2.96 & 8.34 \\
\hline
\end{tabular}

TABLE XV. ONE-SAMPLE T-TEST FOR EVALUATING ENVIRONMENTAL ASSURANCE IN THE SUPPLY CHAIN

\begin{tabular}{|l|l|l|l|}
\hline T-statistics & $\begin{array}{l}\text { Freedom } \\
\text { degree }\end{array}$ & Significance level & Mean difference \\
\hline 7.89 & 217 & 0.01 & 0.40 \\
\hline
\end{tabular}

According to Table 15, T-statistics of environmental assurance (7.9) in supply chain is positive and significant at the level of 0.01 ; it is higher than average. In other words, environmental assurance is a dimension of measuring transparency of inter-organizational information systems in the supply chain.

\section{CONCLUSION}

Question 1: Is transparency of resources regarded as a dimension of measuring transparency of inter-organizational information systems in the supply chain?

Findings of the research on the first question and the role of transparency of resources in measuring transparency of interorganizational information systems indicates with regard to T- statistics (5.57) that the role of transparency of resources is positive and significant in measuring the transparency of interorganizational information systems at the level of 0.01 ; it is higher than average. In other words, transparency of resources is a dimension of measuring transparency of interorganizational information systems in the supply chain. It can be concluded according to the experts' opinion that transparency of resources in the cosmetics industry is in a favorable position. The research findings about role of transparency of resources in measuring transparency of interorganizational information systems are in line with the results of Nilipour Tabatabaei et al. [22], Jafari et al. [23], Mirfakhredini et al. [24], Hosseini et al. [25], Maboudi et al. [26], Shibaji Panda [27], Lee et al. [20], and Sufian et al. [28]. These researchers point to transparency of resources as a component of measuring transparency of inter-organizational information systems. In the interpretation of this finding, one can say that transparency of resources, which refers to the amount of resource assets along with the assets of partners, is in a favorable position in the cosmetic industry. Accordingly, organization will have more information from its partners and competitive advantages in the value of the supply chain will be greater as much as company resources are more.

Question 2: Is inter-organizational trust regarded as a dimension of measuring transparency of inter-organizational information systems in the supply chain?

Findings of the research on the second question and the role of inter-organizational trust in measuring transparency of interorganizational information systems indicates with regard to $\mathrm{T}$ statistics (9.25) that the role of inter-organizational trust is positive and significant in measuring the transparency of interorganizational information systems at the level of 0.01 ; it is higher than average. In other words, inter-organizational trust is a dimension of measuring transparency of interorganizational information systems in the supply chain. It can be concluded according to the experts' opinion that interorganizational trust in the cosmetics industry is in a favorable position. The research findings about role of interorganizational trust in measuring transparency of interorganizational information systems are in line with the results of Mirfakhredini et al. [24], Hosseini et al. [25], Maboudi et al. [26], Shibaji Panda [27], and Lee et al. [20]. These researchers point to inter-organizational trust as a component of measuring transparency of inter-organizational information systems. In the interpretation of this finding, one can say that interorganizational trust is in a favorable position in the cosmetic industry. Accordingly, organization will have more information from its partners and competitive advantages in the value of the supply chain will be greater as much as company resources are more. Inter-organizational trust is a key aspect of communication in the cosmetic industry, which is a kind of capital. Repeat interaction, computation based on benefits, and norms that determine predictability and reliability are counted as source of organizational trust.

Question 3: Is environmental assurance regarded as a dimension of measuring transparency of inter-organizational information systems in the supply chain? 
Findings of the research on the third question and the role of environmental assurance in measuring transparency of interorganizational information systems indicates with regard to Tstatistics (7.89) that the role of environmental assurance is positive and significant in measuring the transparency of interorganizational information systems at the level of 0.01 ; it is higher than average. In other words, environmental assurance is a dimension of measuring transparency of interorganizational information systems in the supply chain. It can be concluded according to the experts' opinion that environmental assurance in the cosmetics industry is in a favorable position. The research findings about role of environmental assurance in measuring transparency of interorganizational information systems are in line with the results of Nilipour Tabatabaei et al. [22], Jafari et al [23], Mirfakhredini et al. [24] Hosseini et al. [25], Maboudi et al. [26], Shibaji Panda [27], Lee et al. [20], and Sufian et al. [28]. These researchers point to environmental assurance as a component of measuring transparency of inter-organizational information systems. In the interpretation of this finding, one can say that Environmental assurance in the cosmetic industry leads to better information sharing and helps to realize organizational performance.

This initial uncertainty of the environment faced by supply chain participants is affected by demand fluctuations and industry speed and they can improve performance by overcoming it.

A major limitation of this study is that it was conducted in a single organization and it cannot be generalized to all organizations. In addition, the number of variables studied was limited to 6 dimensions and a quantitative method was used.

\section{REFERENCES}

[1] A. Amid, Ghodsypour ,S.H., and Obrien.Christopher "A Weighted additive Fuzzy Multiobjective Model for the Supplierselection problem under price Breaks in a Supply chain", International Journal of production Economics, vol.104, no. 2, pp.382-393, 2006.

[2] C. Shphard, H. Gunter, "Measuring supply chain performance: current research and future directions", Internatonal Journal of Produtivity and performance Management, vol. 55, no. 3/4, pp. 242- 258, 2006.

[3] T.Y. Eng, "Mobile supply chain Management: challenges for Implementation", Technovation,vol.26, pp.682-686, 2006.

[4] L. Suhong, B. Ragu-Nathanb, T.S. Rangu- Nathanb, and S. Subba Raob, "Impact of Supply chain Management Practices on Competitive Advantage anad Organizational Performance", Omega the Internatinal Journal of management Science, vol.34, pp.107-124, 2004.

[5] L. Choon, and B. OH, "Evaluating Lnformation Strategic Planning and Evaluating information Sterategic planning and Evaluation System and its Application", Journal of system Integration, vol.10, pp.207-222, 2001.

[6] W. Christina, L. Kee-hung, T.C.E. Chengb, Y.H. Venus Lunb, "The role of IT-enabled collaborative decision making in inter-organizational information integration to improve customer service performance", International Journal of Production Economics, vol.159, pp.56-65, 2015.

[7] A. Rai, R. Patnayakuni, \& N. Seth, "Firm performance impacts of digitallyenabled supply chain integration capabilities", MIS Quarterly, vol. 30, pp.225-246, 2006.

[8] K. K. Kim, S. Y. Ryoo, \& M. D. Jung, "Inter-organizational information sys-tems visibility in buyer-supplier relationships: The case of telecommunicationequipment component manufacturing industry" Omega, vol. 39, pp. 667-676, 2011.
[9] K. Zhu, "Information transparency of business-to-business electronic mar-kets: A game-theoretic analysis", Management Science, vol. 50, pp. 670-685, 2004.

[10] M. Barratt, \& A. Oke, "Antecedents of supply chain visibility in retail supplychains: A resource-based theory perspective", Journal of Operations Management, vol. 25, pp.1217-1233, 2007.

[11] H.-L. Wei, \& E. T. G. Wang, "The strategic value of supply chain visibility:Increasing the ability to reconfigure", European Journal of Information Systems, vol. 19, pp.238-249, 2010.

[12] M. Kiani, F. Moguei, "Socioeconomic factors affecting the use of cosmetics by girls under age 20 Yazdanshahr, Najafabad", Journal of Skin and Beauty, vol. 4 no. 1, pp. 1-9, 2013.

[13] R Samiezadeh, \& R Hosseini "Supply Chain Management (IT) and Information Technology (SCM)", Second National Conference on Information Technology, 2005.

[14] A. Zaheer, B. McEvily, \& V. Perrone, "Does trust matter? Exploring the effectsof interorganizational and interpersonal trust on performance", Organization Sci-ence, vol. 9, pp. 141-159, 1998.

[15] K. K. Kim, S.H. Park, S. Y. Ryoo, \& S. K. Park, "Inter-organizational cooperationin buyer-supplier relationships: Both perspectives", Journal of Business Research, vol. 63, pp. 863-869, 2010.

[16] F.T.S. Chan, A.Y.L. Chong, L. Zhou,"Anempirical investigation of factors affecting ecollaboration diffusion in SMEs". International Journal of Production Economics, vol. 138, no. 2, pp.329-344, 2012.

[17] C.W.Y. Wong, C.Y. Wong, and S. Boon-itt, "Green service practices: performance implications and the role of environmental management systems", Service Science, 2013.

[18] M. Bagheri, "Investigating the relationship between supply chain complexity and financial performance by reviewing the moderating role of complexity leverage of manufacturing companies in Khuzestan Province", Shahid Chamran University of Ahvaz, Faculty of Economics and Social Sciences, 2015

[19] E. Hofmann, E. Hofmann, J. Bosshard, \& J. Bosshard, "Supply chain management and activity-based costing: Current status and directions for the future", International Journal of Physical Distribution \& Logistics Management, vol. 47, no. 8, pp. 712-735, 2017.

[20] J. Lee, H. A. Kao, \& S. Yang, "Service innovation and smart analytics for industry 4.0 and big data environment", Procedia Cirp, vol. 16, pp. 38, 2014.

[21] Z. Ayă̆, F. Samanlioglu, \& G. Büyüközkan, "A fuzzy QFD approach to determine supply chain management strategies in the dairy industry", Journal of Intelligent Manufacturing, vol. 24, no. 6, pp.1111-1122, 2013.

[22] S. Nilipour Tabatabaei, B. Khayambashi, B. Karbasian, \& M. Shariati, "Optimization of Information Technology Application in Supply Chain Management and Marketing of Air Products by AHP Method", New Marketing Research, vol. 2, no. 2, pp.163-143, 2012.

[23] A. Jafari, M. Forghani, \& A. Forghani "Supply Chain Performance Evaluation by Fuzzy Analytical Hierarchy Process (A Case Study of a Food Industry)", Commercial Letter, vol. 15, no. 61, pp.21- 49, 2011.

[24] S. Mirfakhredini, H. Andlib Ardekani, D. Rezaei, M. Rezaei Asl, "Using Multi-Attribute Decision Making Techniques to Assess Supply Chain Risk Factors (Case Study: Information Technology for Small and Medium Enterprises)", Industrial Management Studies, vol. 8, no. 21, pp.107-130, 2011.

[25] S. Hosseini, M. Muhammadi, \& M. Pishvaei, "Supply chain strategy and production system selection", Strategic Management Studies, vol. 1, no.2, pp.89-112, 2010.

[26] M. Maboudi, H. Javanshir, A. Rashidi, \& P. Valipour, "Investigating the Effect of Supply Chain Management on Customer Satisfaction in the Textile Industry", Textile Technology (Textile Science and Technology), vol. 5, no.1, pp.13-23, 2009.

[27] P. Shibaji, "Coordination of a socially responsible supply chain using revenue sharing contract", Transportation Research, vol. 67, pp.2-104, 2014.

[28] Q. Sufian, T. Monideepa, "Supply chain information system sstrategy :Impacts on supply chain performance and firm performance", International Journal of Production Economics, vol. 147, pp.40-350, 2014. 